\title{
THE RELATIONSHIP BETWEEN EUROPEAN UNION LAW AND INTERNATIONAL LAW IN RELATION TO PASSENGER TRANSPORT SERVICES
}

\section{DOROTA AMBROŻUK}

University of Szczecin, Faculty of Management and Economics of Services, POLAND

e-mail: dorota.ambrozuk@wzieu.pl

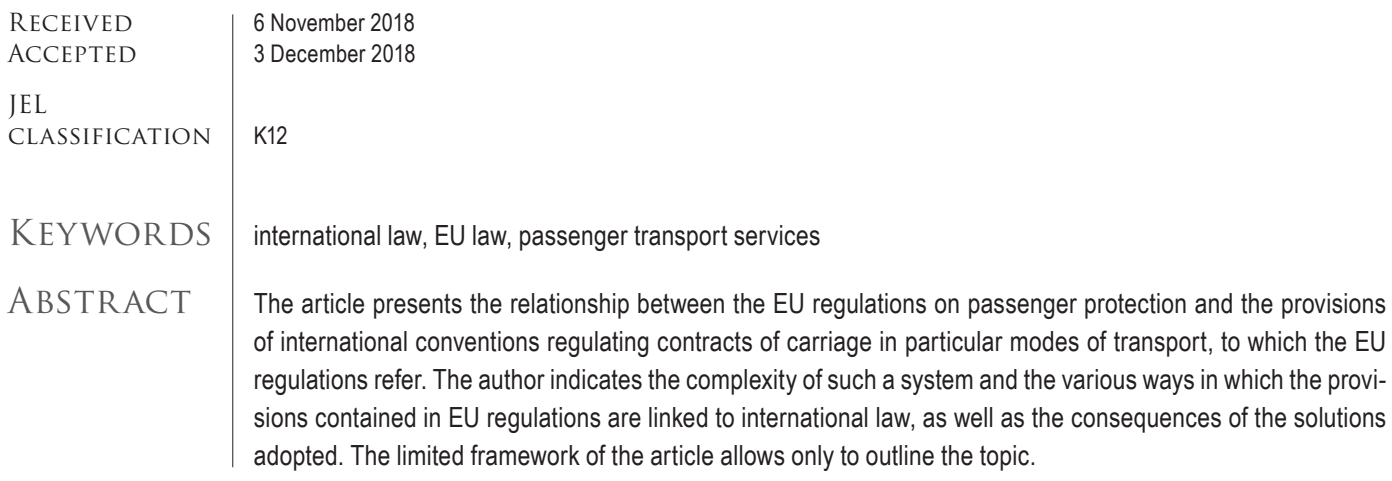
of international conventions regulating contracts of carriage in particular modes of transport, to which the EU regulations refer. The author indicates the complexity of such a system and the various ways in which the provisions contained in EU regulations are linked to international law, as well as the consequences of the solutions adopted. The limited framework of the article allows only to outline the topic.

\section{Introduction}

Since the beginning of the nineteen-nineties, firstly the Community institutions and then the European Union's institutions adopted a number of regulations governing selected issues of passenger transport contracts in 
particular modes of transport. ${ }^{1}$ EU regulations do not contain a complete regulation of the problematics of passenger transport contracts. They only correct and supplement the regulations adopted in conventions. ${ }^{2}$ The EU legislator assumes that, even though the situation of passengers should be improved through a revision of the conventions, amendments to international conventions are nonetheless implemented too slowly. Therefore, it decided to regulate the issue of passenger transport at the Community (EU) level, referring, however, to the existing conventional regimes. The solutions resulting from international conventions therefore constitute an integral part of this system.

\section{Content of the Eurppean passenger protection system}

The EU legislator has thus created a system of passenger protection in which:

a) the rules of the liability of the carrier for the life and health of passengers were tightened in relation to those adopted in international conventions, i.e.: the scope of the causes for which the carrier is liable in air and maritime transport was extended; the limits of the amount of compensation were lifted in air transport and increased in maritime transport; with the exception of bus and coach transport, in all other modes of transport, an obligation to make a quick payment of an advance to passengers and, in the event of their death, to the persons entitled was introduced;

b) the liability of the maritime carrier for the cabin baggage of passengers in maritime transport in comparison to the rules of international conventions was tightened, i.e.: the limits of the amount of compensation were increased and the scope of the causes for which the carrier is liable was widened;

c) flat-rate compensation for denied boarding, delay in carriage, cancellation of carriage was introduced;

1 The system of passenger protection in the EU with respect to the various modes of transport consists mainly of the following regulations: 1) Regulation (EC) No. 2027/97 of the Council of 9 October 1997 on air carrier liability in respect of the carriage of passengers and their baggage by air (OJ EU $1997 \mathrm{~L}$ 285/1) as amended by Regulation (EC) No. 889/2002 of the European Parliament and of the Council of 13 May 2002 (OJ EU 2002 L 140/2, Polish Special Edition 2004, Chapter 7, Volume 6, p. 246); 2) Regulation (EC) No. 261/2004 of the European Parliament and of the Council of 11 February 2004 establishing common rules on compensation and assistance to passengers in the event of denied boarding and of cancellation or long delay of flights, and repealing Regulation (EEC) No. 295/91 (OJ EU 2004 L 46/1, Polish Special Edition 2004, Chapter 7, Volume 8, p. 10); 3) Regulation (EC) No. $1107 / 2006$ of the European Parliament and of the Council of 5 July 2006 concerning the rights of disabled persons and persons with reduced mobility when travelling by air (OJ EU 2006 L 204/1); 4) Regulation (EC) No. 1371/2007 of the European Parliament and of the Council of 23 October 2007 on rail passengers' rights and obligations (OJ EU 2007 L 315/14); 5) Regulation (EC) No. $392 / 2009$ of the European Parliament and of the Council of 23 April 2009 on the liability of carriers of passengers by sea in the event of accidents (OJ EU 2009 L 131/24); 6) Regulation (EC) No. 1177/2010 of the European Parliament and of the Council of 24 November 2009 concerning the rights of passengers when travelling by sea and inland waterway and amending Regulation (EC) No. 2006/2004 (OJ EU 2010 L 334/1); 7) Regulation (EC) No. 181/2011 of the European Parliament and of the Council of 16 February 2011 concerning the rights of passengers in bus and coach transport and amending Regulation (EC) No. 2006/2004 (OJ EU 2011 L 55/1).

2 The international conventions governing the contract of carriage in the various modes of transport are as follows: Warsaw Convention - Convention for the Unification of Certain Rules Relating to International Carriage by Air of 12.10.1929 (Dz.U. of 1933, No. 8, item 49), amended by the Hague Protocol of 28.9.1955 (Dz.U. of 1963, No. 33, item 189), supplemented by the Convention for the Unification of Certain Rules Relating to International Carriage by Air Performed by an Entity other than the Carrier under the Contract of 18.9.1961 (Dz.U. of 1965, No. 25, item 167); Convention for the Unification of Certain Rules for International Carriage by Air of 28.5.1999 (Dz.U. of 2007, No. 37, item 235) - Montreal Convention; Convention concerning International Carriage by Rail (COTIF) of 9 May (Dz.U. of 1985, No. 34, item 158), as amended by the Vilnius Protocol of 3 June 1999 (Dz.U. of 2007, No. 100, item 674), Appendix A. Uniform Rules concerning the Contract of International Carriage of Passengers by Rail (CIV); the Athens Convention relating to the Carriage of Passengers and their Luggage by Sea of 13.12.1974 (Dz.U. of 1987, No. 18, item 108) as amended by the Protocol to the Athens Convention of 19.11 .1976 (Dz.U. of 1994, No. 99, item 479). Poland has not ratified the Protocol of 2002 to the Athens Convention which came into force on 23.4.2014. The EU acceded to this Protocol by virtue of two decisions of the Council of 12.12.2011 (OJ UE L8/1 as amended and OJ UE L 8/13 as amended). 
d) the obligations of carriers towards passengers under the so-called right to assistance in the event of refusal to accept on board a means of transport, cancellation or delay of transport (the right to meals, refreshments, to make a phone call or use the fax machine, accommodation, transport from the port (terminal) to the place of accommodation and back were defined;

e) special protection has been given to disabled passengers and passengers with reduced mobility by expressing directly their right to transport; prohibiting the refusal to sell or book a ticket to such passengers; introducing the obligation of providing them with assistance at the airport, terminal, port or on board a means of transport; allowing them to travel with a carer or a recognized guide dog; in principle, granting full compensation for wheelchairs or other equipment; compulsory taking into account the needs of the abovementioned persons when building the infrastructure of ports, terminals, stations, etc.;

f) the so-called information obligations on carriers to provide information on cancellations and delays, the reasons for them, information on passengers' rights of redress, as well as on the bodies set up to deal with passengers' complaints and how to lodge them were imposed;

g) Member States were required to set up a body or bodies to deal with passengers' complaints with respect to the infringement of their rights under the regulations;

h) an obligation for carriers to take out carrier's third party liability insurance or to obtain other financial security and the possibility of seeking compensation directly by the passenger, on an actio directa basis was introduced (cf. Wesołowski, 2016, pp. 202-203; Ambrożuk, 2014, pp. 12-22).

\section{Problems arising from the complexity of the system}

The adoption of the regulations in question has significantly improved the level of the substantive and legal protection of passengers in the European Union. ${ }^{3}$ However, it raises a number of problems concerning relations with international conventions as well as national law. Limiting ourselves to the former, the following reasons for this state of affairs should be pointed out:

- the incompleteness of the system contained in the regulations, as they govern selected issues only,

- maintaining the branch-specific character of the regulation (as is the case in transport conventions), as well as the existence of a multitude of regulations in certain modes of transport (mainly air transport),

- the use of varied, sometimes very complex and difficult to verify criteria for the application of the various regulations,

- allowing for temporary exemptions from the application of certain provisions of the regulations (see Regulation No. 1371/2007; cf. Wesołowski, 2016, p. 204).

The incompleteness of the EU regulations results in the necessity of applying to certain issues the provisions of international conventions, and sometimes also national law alongside them. It is often difficult to establish which provisions should be applied to a particular contract of carriage, as it may be governed by rules stemming from different legal acts belonging to different bodies (EU, Convention, national). The order of application of these provisions results from the fact that the EU system is based on conventional regulations (it often incorporates

3 The system in question is the subject of, among others, the following studies: Ambrożuk (2014), pp. 11-23; Gospodarek (2011), pp. 56-68; Stec (2012), pp. 433-451; Stec (2007), pp. 247-261; Stec (2010), pp. 4-12; Stec (2010a), pp. 969-985; Koziński (2010), pp. 19-32; Szymajda, Polkowska (2002), pp. 55-80; Pavliha (2013), pp. 226-245, Wesołowski (2014), pp. 399-412. 
the provisions of conventions, extracts from which are annexed to the regulations, see for example: Regulation No. 1371/2007). Therefore, even in the case of internal (domestic) transport governed by the EU regulations, the provisions of international conventions, the content of which has been incorporated into EU regulations, will also apply. Consequently, the provisions of national law will only apply if the issue is not resolved either by provisions of the EU framework or the framework of the conventions (cf. (Wesołowski, 2016, p. 206)). It may also be problematic to establish the scope of application of the individual regulations, even regulations that govern the same mode of transport (cf. Article 1 of Regulation No. 2027/97 as amended by Regulation No. 889/2002, Article 3 of Regulation No. 261/2004 and Article 1 of Regulation No. 1107/2006 in air transport, and Article 2 of Regulation No. 392/2009 and Article 2 of Regulation No. 1177/2010 in transport by sea). Furthermore, the provisions relating to this are very elaborate and contain different criteria. In some cases, if all of them are complied with, the regulation is binding in its entirety and, if some of them are complied with, within a strictly defined scope (cf. Article 2 (1) (c) of Regulation No. 1177/2010, Article 2 (2) and (3) of Regulation No. 181/2011, Article 2 (3) of Regulation No. 1371/2007). Regardless of their own scope of application, the regulations sometimes refer to the scope of the international conventions on which the EU system is built (cf. Article 1 of the Regulation No. 2027/97 as amended by the Regulation No. 889/2002, Article 2 of Regulation No. 1177/2010, Article 2 of Regulation No. 392/2009). Establishing whether a particular regulation should be applied to a particular contract sometimes requires reference also to other legal acts (cf. Article 2 (1) and (2) of Regulation No. 1371, Article 2 of Regulation No. 392/2009). Some criteria for the application of the regulations are difficult to verify, even for lawyers dealing with transport issues (cf. e.g. Article 2 (2) (d) of Regulation No. 1177/2010, which refers to the date of design of the ship, or Article 2 (a) of Regulation No. 392/2009, which refers to the place of registration of the ship, different from the flag State).

\section{Different methods of reference to international conventions}

The issue of the interaction between the provisions of international conventions and those of EU regulations is complicated by the use in the Regulations of different methods of reference to the provisions of international conventions. Aviation regulations, although they refer to the Montreal Convention, do not incorporate its provisions. However, it is an element of EU law as the Union acceded to the Convention. In accordance with Article 216 (2) TFEU (Treaty on the Functioning of the European Union - consolidated version (OJ EU C 2012 326/1)), agreements concluded by the EU are binding for the EU institutions and the Member States. This means that in "EU" relationships apply both the provisions of the Montreal Convention (whether or not a Member State is a party to the Montreal Convention) and the provisions of the EU regulations, which modify and supplement the regulation contained in this Convention.

However, the situation is different with regard to rail and shipping regulations. Although also in this case, the EU also acceded to COTIF and to the Athens Convention as amended by the 2002 Protocol (with the effect resulting from Article 216 (2) TFEU), beforehand, the CIV Convention was largely incorporated into Regulation No. 1371/2007 (rail regulation) through the inclusion of an extract from the Convention in Annex I, and by means of Regulation No. 392/2009 (shipping), it was done likewise with regard to the Athens Convention. However, the incorporation does not involve the entire Convention (provisions on jurisdiction have been exempt, among others, in recognition of the fact that these issues are the exclusive competence of the $E U$ ). This way of referring to the EU law raises the problem as to which provisions should be applied first in EU relations - of an international convention or a regulation. In principle, international agreements concluded by the EU take precedence over secondary law 
(cf. judgment of the CJEU of 3 June 2008 in case C-308/06 Intertanko ECLI:EU:C:2008.312). This would mean that in the case of international transport within the EU, the international convention should be applied first and the regulation should be considered only ancillary. On the other hand, if the provisions of the EU regulations are to strengthen passenger protection with respect to that provided by the provisions of transport conventions, it would be logical for the EU regulations to take precedence (cf. Koziński, 2010, p. 31). This position is confirmed by Article 2 of the Agreement between the European Union and the Intergovernmental Organization for International Carriage by Rail on the accession of the European Union to the Convention concerning International Carriage by Rail (COTIF) of 9 May 1980, as amended by the Vilnius Protocol of 3 June 1999 (OJ EU L 2013 51/8). It follows from this provision that if international carriage is carried out between the EU states, Regulation No. 1371/2007 takes precedence and the COTIF Convention (including its Annex CIV) can only be applied to it in a complementary manner. If, however, the carriage is performed between States party to the COTIF Convention (CIV), of which only one is a member of the EU, then the legal relationship between the parties is governed by the COTIF (CIV) and the regulation applies to it in a complementary manner on the basis of the reference contained in Article 8 (2) of the COTIF. This also applies where both parties to the legal relationship come from a Member State or Member States, as the location of the point of departure or destination in a non-Member State is decisive here.

\section{Consequences of the various methods of reference to international conventions}

A consequence of the application of different methods of reference to conventions is that the same problems arising from the application of the particular regulations can be solved in different ways. One such issue is the period of limitation for claims arising from EU regulations. As a matter of principle, the regulations themselves do not set time limits for the recovery of claims arising therefrom. This raises the question of whether the conventions' provisions in this respect or the provisions of national law should be applied. This is further complicated by the fact that some provisions of the regulations modify only claims arising from provisions of the conventions (e.g. concerning liability for the life and health of passengers), while others constitute a stand-alone basis for claims (e.g. concerning flat-rate compensation for denial of boarding or delay in transport). This was reflected in the judgments of the CJEU relating to air transport. Thus, in its judgment of 22 November 2012 in Case C-139/11 Moré (ECLI:EU:C:2012:741), the Court held that Regulation No. 261/2004 should be interpreted as meaning that the time-limit for bringing an action for the so called flat rate compensation, referred to, inter alia, in Article 7 of that Regulation, is determined in accordance with national law. It thus rejected the possibility of applying to such a claim the two-year limitation period provided for in Article 29 of the Warsaw Convention (to which the wording of Article 35 of the Montreal Convention corresponds at present), on the grounds that the compensation provided for in Regulation No. 261/2004 falls outside the scope of both conventions. The Court stated that this judgement does not contradict the position previously taken in the judgment of 22 October 2009 in Case C-301/08 Bogiatzi (ECLI:EU:C:2009:649), in which it referred to the period of limitation of claims for damages resulting from an accident of which a passenger was a victim, a claim provided for in the aviation conventions and modified only by the regulation. The Court held that in relation to such a claim, there is No. obstacle to the application of the two-year limitation period provided for in Article 29 of the Warsaw Convention. It based its position on a purposive interpretation. The Court pointed out that the purpose of Regulation No. 2027/97 was to increase the level of protection of passengers by replacing certain provisions of the international Convention by the solutions adopted in that Regulation, without, however, excluding the application of the other provisions of the Convention. 
Under aviation law, the Court therefore allowed the possibility of applying periods of limitation set forth in the aviation conventions to those claims which are based on both the conventions and the regulations. In the case of claims which are governed solely by regulations, the issue of the determination of the applicable limitation period should be determined on the basis of solutions provided for in national law.

However, the different method of referring to international conventions results in this reasoning failing to apply to other modes of transport. This issue is of particular relevance in the context of rail transport. Article 60 of the CIV provides for limitation periods for claims brought against the carrier, which apply not only to the claims specifically mentioned but also to "other actions arising from the contract of carriage" (Article 60 (2) of the CIV). As a result, the one-year limitation period referred to in this provision applies to all claims under a contract of carriage governed by the CIV Convention (with the exception of those referred to above), irrespective of whether those claims are governed directly by that Convention or by other provisions. ${ }^{4}$

The provisions of Regulation No. 1371/2007, which modifies and supplements the existing rules contained in the CIV Convention, apply primarily to claims arising from the international carriage of passengers by rail within the territory of the EU. The regulation incorporates the CIV Convention to a large extent, as the extract from this Convention constitutes Annex I to the Regulation. This Annex also contains in Title VI the abovementioned provision of Article 60 of the CIV setting forth the periods of limitation for claims. However, the Annex does not contain Article 60 (4) and (5) of the CIV concerning the suspension of the period of limitation on the grounds that a complaint has been lodged with the carrier and prohibiting the assertion of a time-barred claim). It follows from the provision of Article 11 of Regulation No. 1371/2007 (Liability for passengers and luggage) contained in its Chapter III (Liability of railway undertakings for passengers and their luggage, Articles 11-14) that the liability of railway undertakings in respect of passengers and their luggage is governed, inter alia, by Title VI (Assertion of rights) of Annex I. ${ }^{5}$ Regulation 1371/2007, by means of an annex, regulates the question of the period of limitation for claims for damages brought against the carrier for damages arising from the above mentioned titles.

Regulation 1371/2007 does not regulate however, the period of limitation for the remaining claims of passengers. Article 15 (Liability for delays, missed connections and cancellations) contained in Chapter IV (Delays, missed connections and cancellations) also refers to the Annex, but only to the provisions of Title IV, Chapter II (Liability in case of failure to keep to the timetable, Articles 15-18). It would therefore appear that due to the lack of reference to the provision of Annex I governing the period of limitation for claims and the mentioning also in Chapter IV of the Regulation claims which are not provided for in the CIV Convention but which are governed by the aviation Regulation No. 261/2004 (i.e. the right to flat rate compensation provided for in Article 17 of Regulation No. $1371 / 2007^{6}$ ), allows for the adoption of solutions analogous to those developed in air transport. However, this is not the case because, as already indicated above and as follows from Article 2 of the aforementioned agreement

\footnotetext{
${ }^{4}$ An analogous position with regard to Article 48 (1) of the UR/CIM (Annex B to the COTIF Convention relating to the carriage of goods) governing the period of limitation, which also refers to "other actions arising from the contract of carriage", supports, for example, Freise, 2009, p. 1399; see also the OGH judgment of 26 August 2004, similarly, Koller (2013), p. 449.

${ }^{5}$ Article 11 of Regulation No. 1371/2007, in addition to the reference to Title VI of Annex I, refers to that Annex in respect of Title IV (Liability of the carrier) of Chapter I (Liability in case of death of, or personal injury to, passengers), Chapter III (Liability in respect of hand luggage, animals, registered luggage and vehicles) and Chapter IV (Common provisions) and Title VII (Relations between carriers).

${ }^{6}$ According to Article 17 (1) of Regulation No. 1371/2007, a passenger may request compensation amounting to $25 \%$ of the ticket price for a delay of 60 to 119 minutes to the final destination and $50 \%$ of the ticket price for a delay of 120 minutes or more.
} 
of 23 June 2011 on the accession of the EU to COTIF, the provisions of the CIV Convention apply to international rail transport within the territory of the EU in areas not regulated by EU law. Therefore, the periods of limitation laid down in Article 60 (2) of the CIV (one year and, where the damage results from an act or omission committed either with intent to cause damage or recklessly and with knowledge that such damage would probably result, two years) will apply to all claims under a contract of carriage governed by the CIV Convention. The exception is claims for damages in respect of the death of, or personal injury to, passengers, where the three-year limitation period laid down in Article 60 (1) of the CIV applies. Therefore, the limitation periods provided for in Article 60 (2) of the CIV are also appropriate for those claims which are not expressly provided for in the CIV Convention if the contract of carriage itself is subject to that Convention. This also applies to claims for which the sole basis is Regulation No. 1371/2007. However, where the carriage is of an international and EU nature but the CIV Convention does not apply to it, ${ }^{7}$ the period of limitation should be determined on the basis of the provisions of the applicable national law.

\section{Conclusions}

As can be seen above, the relationships between EU regulations and the provisions of international conventions on passenger transport are not only complex, but also heterogeneous across the particular modes of transport. As a result of this, analogous problems have to be solved differently, which does not favor the effective functioning of the passenger protection system.

After substantive changes, the next stage of works on the EU law regarding the transport of persons should be the formal ordering of the system. It is about its readability and relative uniformity of regulation. Not all differences between the regulations applicable in particular modes of transport are justified by different technical and technological conditions appropriate for these branches. At the same time, it seems that one should strive for a situation in which only one regulation concerning passenger rights will apply in each mode of transport.

\section{References}

Ambrożuk, D. (2014). Kształtowanie się europejskiego prawa przewozu osób. Prace Naukowe Uniwersytetu Ekonomicznego we Wrocławiu, 362, 11-24. DOI: 10.15611/pn.2014.362.01.

Freise, R. (2009). Münchener Kommentar zum Handelsgesetzbuch. Transportrecht. München: C.H. Beck/Franz Vahlen.

Gospodarek, J. (2011). Cel i zakres ochrony konsumenta na rynku usług transportowych w świetle prawa Unii Europejskiej. Zeszyty Naukowe Uniwersytetu Szczecińskiego, 694. Problemy Zarządzania, Finansów i Marketingu, 22, 55-68.

Koller, I. (2013). Transportrecht. Kommentar. München: C.H. Beck.

Koziński, M.H. (2010). Odpowiedzialność cywilna morskiego przewoźnika pasażerów według prawa Unii Europejskiej. Prace Wydziału Nawigacyjnego Akademii Morskiej w Gdyni, 25, 19-32.

Pavliha, M. (2013). Enlightenment of the European Attitude Towards Passanger Richts: In dubio pro consumatore. European Transport Law, 48 (3), 226-245.

7 The provisions of the CIV will not apply to international transport between stations located within the territory of neighboring countries where the infrastructure of those stations is managed by one or more managers belonging to one and the same country. Member States may also conclude agreements providing for deviations from the provisions of the CIV in respect of transport operations performed exclusively between two stations located on both sides of the border, where No. other station is located between them. In addition, in order to carry out transport operations in transit through a country which is not a Member State, the competent States may conclude agreements providing for the non-application of the CIV. 
Stec, M. (2007). O niektórych postaciach niewykonania lub nienależytego wykonania pasażerskiej umowy przewozu lotniczego (na kanwie rozporządzenia Parlamentu i Rady Unii Europejskiej z 2004 r.). In: W kierunku europeizacji prawa prywatnego. Księga Pamiątkowa dedykowana Profesorowi Jerzemu Rajskiemu (pp. 247-261). Warszawa: C.H. Beck.

Stec, M. (2010). Przesłanki odstąpienia od umowy przewozu w europejskim pasażerskim transporcie lotniczym w rozporządzeniu Parlamentu i Rady (WE) nr 261/2004. Europejski Przegląd Sądowy, 4, 4-12.

Stec, M. (2010a). Ochrona pasażera w transporcie kolejowym w świetle Rozporządzenia (WE) nr 1371/2007 Parlamentu Europejskiego i Rady. In: M. Modrzejewska (ed.), Prawo handlowe XXI wieku, Czas stabilizacji, ewolucji czy rewolucji. Księga Pamiątkowa dedykowana Profesorowi Józefowi Okolskiemu (pp. 969-985). Warszawa: Wolters Kluwer.

Stec, M. (2012). Ochrona pasażera w transporcie autobusowym w świetle rozporządzenia Parlamentu Europejskiego i Rady z 16 lutego 2011 r. nr 181/2011 dotyczącego praw pasażerów w transporcie autobusowym i autokarowym. In: Rozprawy z prawa własności intelektualnej prawa prywatnego międzynarodowego. Księga pamiątkowa dedykowana Profesorowi Bogusławowi Gawlikowi (pp. 433-451). Warszawa: LexisNexis Polska.

Szymajda, I, Polkowska, M. (2002). Ochrona praw pasażerów lotniczych w prawie Wspólnoty Europejskiej. Studia Europejskie, 4, 55-80.

Wesołowski, K. (2014). Konsekwencje sposobu unormowania ochrony pasażerów w prawie Unii Europejskiej. Prace Naukowe Uniwersytetu Ekonomicznego we Wrocławiu, 362, 399-412. DOI: 10.15611/pn.2014.362.30.

Wesołowski, K. (2016). Multicentryczność regulacji usługi przewozu osób. In: Marketing i Zarządzanie, 1 (42), 201-215, DOI: 10.18276/ miz.2016.42-14.

Cite this article aS: Ambrożuk, D. (2018). The relationship between European Union law and international law in relation to passenger transport services. European Journal of Service Management, 4 (28/1), 7-14. DOI: 10.18276/ejsm.2018.28/1-01. 